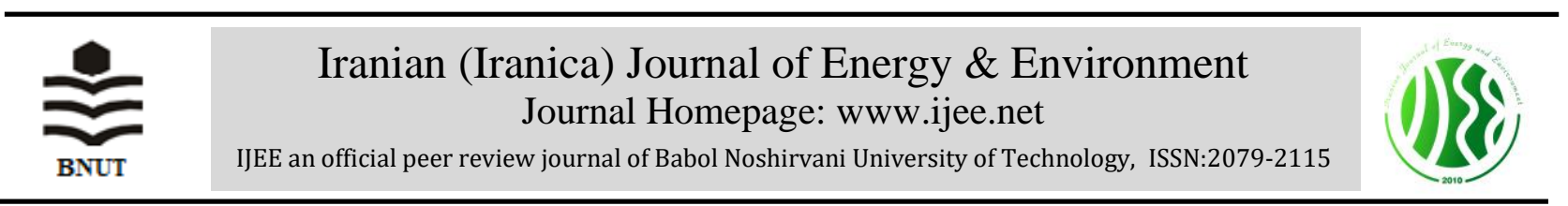

Technical Note

\title{
Application of Aspen HYSYS for Predicting the Effects of Impurities on Thermodynamic Performance of Glycerol Autothermal Reforming for Hydrogen Production
}

\author{
S. A. Azeez*, U. Garba, B. G. Danshehu \\ Department of Mechanical Engineering, Faculty of Engineering and Environmental Design, Usumanu Danfodiyo University, Sokoto, Nigeria
}

\section{$P A P E R \quad I N F O$}

\section{Paper history:}

Received 19 November 2019

Accepted in revised form 22 February 2020

\section{Keywords:}

Efficiency

Energy

Exergy

Optimization

\begin{abstract}
$A \begin{array}{lllllllllllllllll}A & S & R & A & C & T\end{array}$
Hydrogen production from glycerol via autothermal reforming (ATR) has been widely investigated. However, little is known about the influence of impurities in glycerol on thermodynamic performance of the process. This study focused on the effects of impurities in glycerol on hydrogen productivity, energetic and exergetic efficiencies. The model of the entire process was simulated under thermoneutral condition in Aspen HYSYS using pure glycerol (PG) and crude glycerol (CG) as feeds. The two cases were optimized for maximum hydrogen production. From the optimized results, the hydrogen production per mole of the feed was 4.937 and 6.160 for the case of PG and CG, respectively. The thermal and exergetic efficiency of PG as feed were computed as $79.51 \%$ and $57.04 \%$ while that of CG were obtained to be 77.7 and $54.08 \%$, respectively. The exergy destroyed to produce 1 mole of $\mathrm{H}_{2}$ was found to be $133.5 \mathrm{~kJ}$ and $157.3 \mathrm{~kJ}$ for the case of $\mathrm{PG}$ and $\mathrm{CG}$, respectively. It could be concluded that the presence of other constituents in CG contributed to increase in hydrogen productivity by increasing the energy demand of the plant but due to increase in both energy and exergy input, they decrease both the thermal and exergetic efficiencies.
\end{abstract}

doi: $10.5829 /$ ijee.2020.11.01.08

\section{INTRODUCTION}

The continuous release of greenhouse gases into the atmosphere and sudden change in climate conditions causing detrimental effect on our environment accounted for growing research in finding energy source that can replace fossil fuels. It has been recognized in the past that hydrogen as an energy carrier has great potential to replace fossil fuel in the future. It was stated in Kapdan and Kargi [1] that a clean energy carrier yields 2.75tons more energy than hydrocarbon fuel. The feedstock for hydrogen production can either be fossil fuel source (coal and natural gas) or alternative source (solar, nuclear and biomass). However, environmental friendly hydrogen production especially from bio-renewable feedstocks is required as mitigating technology. There is dramatic increase in crude glycerol production due to rapid expansion of biodiesel industry. Purified glycerol is used in cosmetics, food and pharmaceutical industries but high purification cost and availability of excess crude glycerol in the market made biodiesel producers to seek for alternative method for its utilization. One of the successive routes considered is the use of crude glycerol for hydrogen production. Biodiesel and glycerol are produced when vegetable oil and fats with alcohol in the presence of homogenous catalyst such as sodium or potassium hydroxide undergo transesterification and hydrolysis [2]. CG contains methanol, free fatty acid, water, glycerides, soap and fatty acids methyl esters as impurities [3]

Various techniques such as steam reforming, partial oxidation, dry reforming, aqueous phase reforming and ATR have been considered for hydrogen production [4-8]. In autothermal reforming, the required energy for the necessary reactions to take place is supplied by exothermic oxidation reaction. Therefore, the reforming technology considered for simulation in this study was autothermal reforming due to its energy efficiency and process stability. For these reasons, many works have been centered on improving hydrogen productivity in ATR of glycerol.

A thermodynamic analysis of autothermal reforming considering crude glycerol as a mixture glycerol and methanol using HYSYS was carried out by Authayanun et al. [9]. The result they obtained showed better performance when the ratio of glycerol to methanol increases. Ortiz et al. [10] conducted a thermodynamic analysis of glycerol autothermal 
reforming within a pressure range of 200-300 atm for pure and pre-treated glycerol using Gibbs free energy minimization approach. Under thermoneutral conditions, the optimum operating parameters were $0.407,800^{\circ} \mathrm{C}$ and 99 for oxygen-glycerol, temperature and steam-glycerol, respectively. Abdulgani [11] in his research carried out production of renewable hydrogen from synthetics crude glycerol through ATR process. The best operating conditions were found experimentally in a packed bed reactor to be a reforming temperature of $575^{\circ} \mathrm{C}$, steam-glycerol of 2.6 , and oxygen-glycerol of 0.125 . Many studies have been devoted to thermodynamic analysis of glycerol ATR process using Gibbs minimization technique [12-14]. Jimmy et al. [14] worked on thermodynamic modeling of hydrogen production from autothermal reforming of synthetic crude glycerol using Gibbs free energy minimization method. The optimum operating conditions under thermoneutral condition was obtained at 3.6, 0.75 and $927 \mathrm{~K}$ for steam-crude glycerol ratio, oxygen-crude glycerol ratio and adiabatic temperature, respectively. Da Silva et al. [15] focused their study on optimization of the operating conditions of autothermal reforming of glycerol for hydrogen production for fuel cell using HYSYS as a process simulator. The simulation result showed that an optimum air to feed and steam to feed ratios of 5.5 and 3.5 , respectively produced $34.7 \%$ of hydrogen.

In recent decades, the use of both energy and exergy analysis for assessing the performance of a system has attracted the interest of the researchers. Using various assessment tools, Hajjaji et al. [16] studied the process simulation of production of hydrogen via autothermal reforming of PG. They obtained 78.7 and $67.8 \%$ as the optimum thermal and exergetic efficiencies, respectively. They also recommended $\mathrm{S} / \mathrm{G}=5.5, \mathrm{O} / \mathrm{G}=0.96, \mathrm{~T}=900 \mathrm{~K}$ as the optimum conditions for the entire process of hydrogen production. However, most of the works carried out in this field is concentrated on evaluation of thermodynamic performance of pure glycerol ATR reactor and/or catalysis in the system, but energetic and exergetic assessment of the entire process of hydrogen production from crude glycerol through ATR is very scarce in literature.

This research work is aimed to determine the effect of impurities in crude glycerol on thermal efficiency, exergetic efficiency and hydrogen productivity of glycerol autothermal reforming process. This was achieved by modeling and thermodynamic analysis of an optimized system of hydrogen production from both PG and CG through autothermal reforming.

\section{MATERIAL AND METHODS}

In this study, hydrogen production via autothermal reforming using both PG and CG as feeds was investigated. Aspen Hysys was used to design and simulate the entire hydrogen production process. Peng-Robinson Stryjek-Vera (PRSV) equation of state was used to determine the physical and transport properties of the streams in the model. The simulation results were then optimized before hydrogen productivity, energetic and exergetic performances of the system were determined. The effect of the impurities was determined by comparing the simulation results and thermodynamic performance of the reforming processes using the two feeds.

\section{Model development and process simulation}

A simplified flow diagram for hydrogen production from glycerol via ATR process is shown in Figure 1. The Gibb's reactor considered as autothermal reformer was used to determine the equilibrium composition of the gas products. The possible reactions in the autothermal reactor are as follow:

Steam reforming

$$
\begin{array}{cc}
\mathrm{C}_{3} \mathrm{H}_{8} \mathrm{O}_{3}+3 \mathrm{H}_{2} \mathrm{O} \leftrightarrow 7 \mathrm{H}_{2}+3 \mathrm{CO}_{2} & \Delta \mathrm{H}_{298 \mathrm{~K}}=127.67 \mathrm{~kJ} / \mathrm{mol} \\
\mathrm{CH}_{3} \mathrm{OH}+\mathrm{H}_{2} \mathrm{O} \leftrightarrow 3 \mathrm{H}_{2}+\mathrm{CO}_{2} & \Delta \mathrm{H}_{298 \mathrm{~K}}=49.5 \mathrm{~kJ} / \mathrm{mol} \\
\mathrm{C}_{3} \mathrm{H}_{7} \mathrm{OH}+5 \mathrm{H}_{2} \mathrm{O} \leftrightarrow 9 \mathrm{H}_{2}+3 \mathrm{CO}_{2} & \Delta \mathrm{H}_{298 \mathrm{~K}}=283.8 \mathrm{~kJ} / \mathrm{mol}
\end{array}
$$

Partial oxidation

$$
\begin{array}{cc}
\mathrm{C}_{3} \mathrm{H}_{8} \mathrm{O}_{3}+1.5 \mathrm{O}_{2} \leftrightarrow 4 \mathrm{H}_{2}+3 \mathrm{CO}_{2} & \Delta \mathrm{H}_{298 \mathrm{~K}}=-603.5 \mathrm{~kJ} / \mathrm{mol} \\
\mathrm{CH}_{3} \mathrm{OH}+0.5 \mathrm{O}_{2} \leftrightarrow 2 \mathrm{H}_{2}+\mathrm{CO}_{2} & \Delta \mathrm{H}_{298 \mathrm{~K}}=-102.5 .5 \mathrm{~kJ} / \mathrm{mol} \\
\mathrm{C}_{3} \mathrm{H}_{7} \mathrm{OH}+2.5 \mathrm{O}_{2} \leftrightarrow 4 \mathrm{H}_{2}+3 \mathrm{CO}_{2} & \Delta \mathrm{H}_{298 \mathrm{~K}}=-926.2 \mathrm{~kJ} / \mathrm{mol}
\end{array}
$$

Water gas shift

$$
\mathrm{CO}+\mathrm{H}_{2} \mathrm{O} \leftrightarrow \mathrm{H}_{2}+\mathrm{CO}_{2}
$$

$$
\Delta \mathrm{H}_{298 \mathrm{~K}}=-41.8 \mathrm{~kJ} / \mathrm{mol}
$$

Methanation reactions

$$
\begin{array}{ll}
\mathrm{CO}+3 \mathrm{H}_{2} \leftrightarrow \mathrm{CH}_{4}+\mathrm{H}_{2} \mathrm{O} & \Delta \mathrm{H}_{298 \mathrm{~K}}=-206.8 \mathrm{~kJ} / \mathrm{mol} \\
\mathrm{CO}_{2}+4 \mathrm{H}_{2} \leftrightarrow \mathrm{CH}_{4}+2 \mathrm{H}_{2} \mathrm{O} & \Delta \mathrm{H}_{298 \mathrm{~K}}=-165 \mathrm{~kJ} / \mathrm{mol}
\end{array}
$$

Methane dry reforming

$\mathrm{CO}_{2}+\mathrm{CH}_{4} \leftrightarrow 2 \mathrm{H}_{2}+2 \mathrm{CO}$

$$
\Delta \mathrm{H}_{298 \mathrm{~K}}=246 \mathrm{~kJ} / \mathrm{mol}
$$

Glycerol reforming

$\mathrm{C}_{3} \mathrm{H}_{8} \mathrm{O}_{3}+\mathrm{H}_{2} \mathrm{O}+0.5 \mathrm{O}_{2} \leftrightarrow 2 \mathrm{CO}_{2}$
$+\mathrm{CO}+5 \mathrm{H}_{2}$

$\Delta \mathrm{H}_{298 \mathrm{~K}}=-78.3 \mathrm{~kJ} / \mathrm{mol}$

Methanol reforming

$$
\begin{aligned}
& \mathrm{CH}_{3} \mathrm{OH}+0.25 \mathrm{H}_{2} \mathrm{O}+0.125 \mathrm{O}_{2} \leftrightarrow \\
& 0.5 \mathrm{CO}_{2}+0.5 \mathrm{CO}+2.25 \mathrm{H}_{2} \\
& \mathrm{C}_{3} \mathrm{H}_{7} \mathrm{OH}+2 \mathrm{H}_{2} \mathrm{O}+\mathrm{O}_{2} \leftrightarrow 2 \mathrm{CO}_{2}+\quad \Delta \mathrm{H}_{298 \mathrm{~K}}=9.6 \mathrm{~kJ} / \mathrm{mol} \\
& \mathrm{CO}+6 \mathrm{H}_{2}
\end{aligned}
$$

Preferential oxidation

$$
\begin{array}{lr}
\mathrm{CO}+0.5 \mathrm{O}_{2} \leftrightarrow \mathrm{CO}_{2} & \Delta \mathrm{H}_{298 \mathrm{~K}}=-570 \mathrm{~kJ} / \mathrm{mol} \\
\mathrm{H}_{2}+0.5 \mathrm{O}_{2} \leftrightarrow \mathrm{H}_{2} \mathrm{O} & \Delta \mathrm{H}_{298 \mathrm{~K}}=-480 \mathrm{~kJ} / \mathrm{mol}
\end{array}
$$

The CO clean up section was represented in the process flow diagram by three shift reactors modeled by Gibbs reactors and preferential oxidation reactor (COPOX) modeled by conversion reactor. The three shift reactors and their temperature ranges are as follow: High Temperature Shift reactor (HTSR, $300-450^{\circ} \mathrm{C}$ ), Moderate Temperature Shift reactor (MTSR, 220-270 ${ }^{\circ} \mathrm{C}$ ) and Low Temperature Shift reactor (LTSR, $180-250^{\circ} \mathrm{C}$ ). The reaction taking place in the shift reactors is shown in Equation (7) while that of COPOX is given in Equations (14) and (15). In COPOX, the stream exiting the LTSR is mixed with air and CO is selectively 


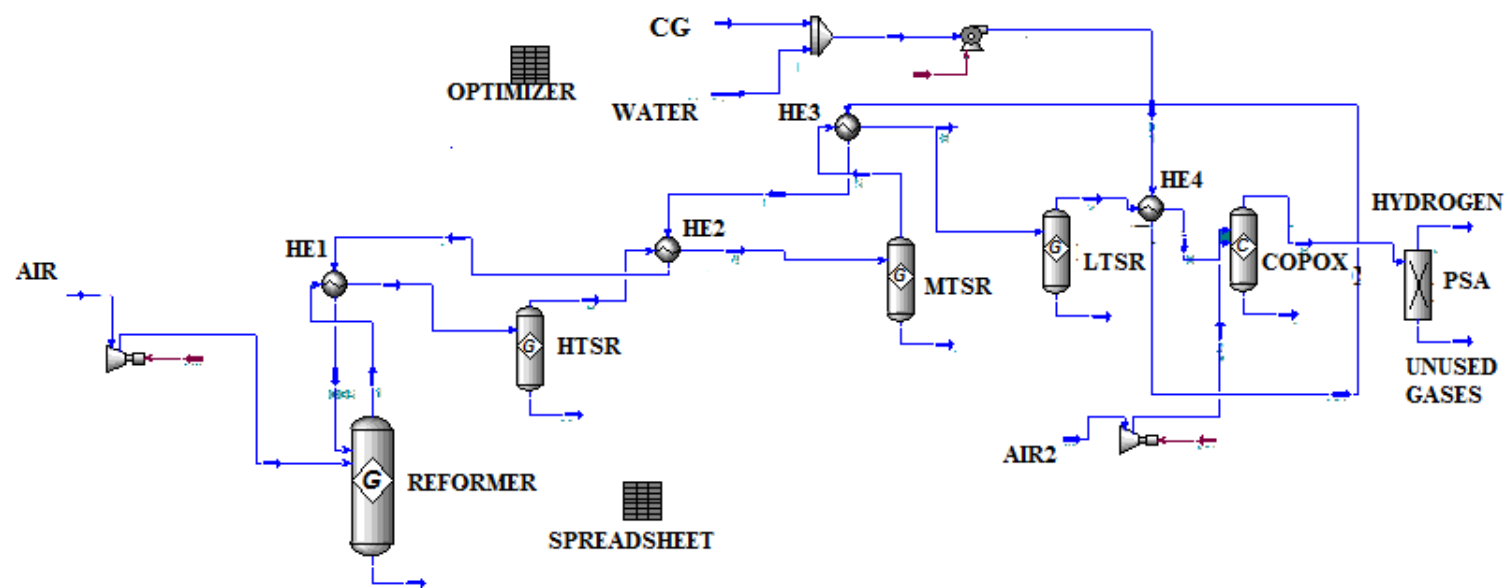

Figure 1. The Process flow diagram of crude glycerol autothermal reforming

oxidized to $\mathrm{CO}_{2}$ in the presence of noble metal [17]. However, small amount of hydrogen oxidizes to water [18]. In this work, the molar concentration of $\mathrm{CO}$ lower than the maximum allowable limit (10ppm) for fuel cell application was considered by varying the air molar flow rate with $2 \%$ hydrogen conversion. Heat exchangers are installed between the reactors because of the exothermic nature of the reaction. The purification section is solely based on pressure swing adsorption modeled as component splitter. The hydrogen rich gases exiting $\mathrm{CO}$ clean section was separated into hydrogen stream with $99.98 \%$ percentage purity and unused gases in the purification section. The process was designed by taking the specified temperature range of the reactors into consideration. The process model and the analysis were carried out on the following assumptions

- All the components possess adiabatic boundaries.

- Kinetic and potential exergy are overlooked for all system components.

- The reference temperature and pressure are $25^{\circ} \mathrm{C}$ and $1 \mathrm{~atm}$.

- Air is considered as an ideal gas with molar concentration of $21 \%$ Oxygen and $79 \%$ Nitrogen.

- The feeds conditions are at standard temperature and pressure.

- Formation of coke is overlooked due to negligible concentration.

- $\mathrm{S} / \mathrm{CG}$ and $\mathrm{A} / \mathrm{CG}$ of 3.5 and 5.5 are considered, respectively.

- The use of catalyst is not considered.

- The outlet stream temperature of the reactors is considered as reactor's temperature.

The compositions of crude glycerol depend on the raw materials and processes used in biodiesel plant. The input values for the simulation of the base case are presented in Table 1. The crude glycerol composition is based on synthetic crude glycerol composition reported in literature [11].

TABLE 1. Feed compositions for the base case (CG)

\begin{tabular}{lcccc}
\hline CG constituents & Glycerol & Methanol & Soap & Oleic acid \\
\hline $\begin{array}{l}\text { Composition } \\
\text { (weight \%) }\end{array}$ & 0.51 & 0.13 & 0.32 & 0.04 \\
\hline
\end{tabular}

\section{Process optimization}

The whole process was optimized using the optimizer tool in Aspen HYSYS for maximum hydrogen production at a constant flow rate of both PG and CG. The optimization problem is represented mathematically as given in Equations (16) - (29).

$$
F(x)=\max \left(M_{H_{2}}^{\text {out }}\right)
$$

The problem was subject to the following constraints

$$
\begin{aligned}
& 300<\text { stream } 3<450{ }^{\circ} \mathrm{C} \\
& 220<\text { stream } 5<270{ }^{\circ} \mathrm{C} \\
& 180<\text { stream } 7<450{ }^{\circ} \mathrm{C} \\
& \max \left(M_{H_{2}}^{\text {out }}\right)<10 \mathrm{ppm}
\end{aligned}
$$

The temperature constraint illustrated in Equations (17) - (19) were considered in order to fulfill temperature constraints of the reactors. The component molar concentration of $\mathrm{CO}$ was assumed not to be greater than 10ppm for the purpose of fuel cell applications. The optimizer algorithm used for this case was sequential quadratic programming because of its ability to handle equality and inequality constraints. Also, the region where the optimal solution of this case was searched for is defined on each manipulated variable as given in Equations $(21)-(23)$.

$$
\begin{aligned}
& 300<\text { Air }<700 \mathrm{kgmol} / \mathrm{hr} \\
& 200<\mathrm{H}_{2} \mathrm{O}<500 \mathrm{kgmol} / \mathrm{hr} \\
& 10<\text { Air } 2<80 \mathrm{kgmoppl} / \mathrm{hr}
\end{aligned}
$$

\section{Thermodynamic analysis}

The system performance based on first law of thermodynamics can be estimated by its thermal efficiency. It is expressed as the ratio of energy output to energy input as shown in Equation (24).

$$
\eta_{\text {thermal }}=\frac{\mathrm{M}_{\mathrm{H}_{2}} \times \mathrm{LHV}_{\mathrm{H}_{2}}}{\left(\mathrm{M}_{\mathrm{i}} \times \mathrm{LHV}_{\mathrm{i}}\right)+\mathrm{W}_{\mathrm{comp} 1}+\mathrm{W}_{\mathrm{comp} 2}+\mathrm{W}_{\text {pump }_{\mathrm{i}}}}
$$

where, $\mathrm{M}_{\mathrm{i}}$ and $\mathrm{LHV}_{\mathrm{i}}$ are the molar flow and the lower heating 
value of feed " $\mathrm{i}$ " respectively, $\mathrm{M}_{\mathrm{H}_{2}}$ and $\mathrm{LHV}_{\mathrm{H}_{2}}$ are the molar flow and the lower heating value of hydrogen; $\mathrm{W}_{\text {comp1 }}$, mechanical work of the first compressor; $W_{\text {comp2 }}$, mechanical work of the second compressor; $\mathrm{W}_{\text {pump }_{\mathrm{i}}}$, mechanical work for feed pumping.

The exergy transfer associated with flow was calculated by adding the physical and chemical exergy of a particular stream.

The physical exergy, $E X^{p h}$ of a stream is calculated by Equation (25).

$$
E X^{p h}=M\left\{\left(H-H_{o}\right)-\mathrm{T}_{\mathrm{o}}\left(\mathrm{S}-\mathrm{S}_{\mathrm{o}}\right)\right\}
$$

where, $M$ is the molar flow rate of a stream; $H$ and $S$, the specific enthalpy and entropy calculated at the stream condition; $H_{o}$ and $S_{o}$ are the specific enthalpy and entropy calculated at the atmospheric temperature $\left(T_{o}\right)$ and pressure $\left(P_{o}\right)$.

The chemical exergy, $E X^{c h}$ of a substance not present in the environment is obtained by using Equation (26).

$$
E X^{c h}=-\Delta G+\sum_{p} n E X^{c h}-\sum_{R} n E X^{c h}
$$

where, $\Delta G$ is the change in standard Gibb's free energy of the reaction; $\mathrm{n}$, number of mole of species taking part in the reaction; $\mathrm{P}$, product side of the reaction and $\mathrm{R}$, the reactant side of the product.

The chemical exergy $E X_{S}^{c h}$ of a stream containing more than one component $\mathrm{k}$ of mole fraction $\mathrm{X}$ can be determined by Equation (27).

$$
E X_{s}^{c h}=\sum_{k}^{1} X_{k} E X^{c h k}+R T_{o} \sum_{k}^{1} X_{k} \ln \left(X_{k}\right)
$$

The exergy associated with heat transfer, $E x_{q}$ and work transfer, $E X_{w}$ is estimated by Equations (28) and (29) respectively.

$$
\begin{aligned}
& E x_{q}=\left(1-T_{o} / T\right) Q \\
& E X_{w}=W
\end{aligned}
$$

The internal exergy destruction, $I$ within the control volume is calculated by using Equation (30).

$$
\begin{aligned}
& I=\sum E X_{\text {in }}-\sum E X_{\text {out }} \\
& \sum E X_{\text {in }}=E X_{\text {gly }}+E X_{\text {water }}+E X_{\text {air }}+ \\
& E X W_{\text {comp } 1}+E X W_{\text {comp } 2}+W_{\text {pump }_{\mathrm{i}}} \\
& \sum E X_{0 u t}=E X_{\text {hydro }}+E X_{\text {unused }} \\
& E X_{\text {unused }}=E X_{\text {waste }}+I
\end{aligned}
$$

where, $Q$ is the quantity of heat transfer; $\mathrm{R}$, gas constant; $E X_{\text {hydro }}$, exergy flow of hydrogen rich stream; $E X_{\text {unused }}$, exergy that leave the system; $E X_{\text {waste }}$, exergy associated with waste stream; $\sum E X_{\text {in }}$, total exergy flow into the system; $\sum E X_{\text {out }}$, total exergy flowing out of the system; $E X_{g l y}$, exergy associated with glycerol flow; $E X_{\text {water }}$, flow exergy of water; $E X_{\text {air }}$, flow exergy of air; $E X W_{\text {comp } 1}, E X W_{\text {comp } 2}$ and $\mathrm{W}_{\text {pump }_{\mathrm{i}}}$ are the exergy flow associated with mechanical work for compressor 1 , compressor 2 and feed pump respectively.
The exergetic efficiency of the overall system was evaluated by Equation (33).

$$
E X_{\text {eff }}=E X_{\mathrm{H}_{2}} / \sum E X_{\text {in }}
$$

\section{RESULTS AND DISCUSSION \\ Simulation results}

The components molar flow rate of effluents from reformer and PSA using PG and CG as feeds are presented in Table 2. $346.786 \mathrm{kgmole} / \mathrm{h}$ of hydrogen was obtained from PG which was later increased by $40 \%$ via shift and partial oxidation reactions installed for $\mathrm{CO}$ clean-up process. It is also indicated in Table that the $\mathrm{CO}$ concentration was reduced below the specified limit. Furthermore, the CO clean-up section was able to increase hydrogen molar flow rate by $32.04 \%$ with $447.270 \mathrm{kgmole} / \mathrm{h}$ of it being produced by the reformer in the case of CG. It is well established in the table that more methane was generated in the process plant when CG was used as feed, this might be as result of the presence of alcohol and fatty acids in the feed. With these, the model developed is in conformity with the anticipated results.

\section{Process optimization}

From the results obtained, the base case possesses good hydrogen productivity relatively to values reported by previous researchers. However, the base case system still has potential for improvement in hydrogen production. The optimized results are presented in Table 3. The hydrogen production increase of $3.16 \%$ was accomplished by reducing the flow rate of the water, air to the reformer and air to the COPOX when PG was considered as feed. In the case of CG, the optimization results showed an increment of $3.62 \%$ at the detriment of increase in both air and water flow rate to the reformer.

\section{Energy analysis}

As shown in Table 4, the presence of impurities in CG caused $24.77 \%$ increment in hydrogen production. This occurs as a result of higher stoichiometric hydrogen content in the feed. Therefore, the higher the ratio of glycerol to methanol in CG, the higher the hydrogen productivity and vice-versa. This is

TABLE 2. The component molar flow rate of effluents in the system

\begin{tabular}{lcccccc}
\hline & \multicolumn{2}{c}{ PG } & & \multicolumn{2}{c}{ CG } \\
\cline { 1 - 3 } \cline { 6 - 7 } Components (Kgmol/hr) & & ATR & PSA & & ATR & PSA \\
\hline $\mathrm{CH}_{4}$ & 0.365 & 0.365 & & 17.527 & 17.527 \\
$\mathrm{H}_{2} \mathrm{O}$ & 402.261 & 270.498 & & 293.618 & 150.126 \\
$\mathrm{CO}$ & 143.957 & 0.003 & & 162.922 & 0.011 \\
$\mathrm{CO}_{2}$ & 155.596 & 299.562 & & 153.527 & 316.457 \\
$\mathrm{H}_{2}$ & 346.786 & 478.560 & & 447.270 & 590.582 \\
$\mathrm{~N}_{2}$ & 446.041 & 485.561 & & 446.134 & 485.669 \\
$\mathrm{GLY}$ & 0.000 & 0.0000 & & - & - \\
$\mathrm{CGLY}$ & 0.000 & - & & 0.000 & 0.000 \\
$\mathrm{O}_{2}$ & 0.000 & 0.0000 & & 0.000 & 0.000 \\
\hline
\end{tabular}


TABLE 3. Results of the optimization study

\begin{tabular}{lccccc}
\hline & \multicolumn{2}{c}{ PG } & & \multicolumn{2}{c}{ CG } \\
\cline { 2 - 3 } \cline { 5 - 6 } & $\begin{array}{c}\text { Base } \\
\text { Case }\end{array}$ & $\begin{array}{c}\text { Optimized } \\
\text { Case }\end{array}$ & & $\begin{array}{c}\text { Base } \\
\text { Case }\end{array}$ & $\begin{array}{c}\text { Optimized } \\
\text { Case }\end{array}$ \\
\hline $\begin{array}{l}\text { Objective Function } \\
M_{H_{2} \text { out }} \text { (kgmole/hr) }\end{array}$ & 478.560 & 493.700 & & 590.582 & 616.976 \\
Control Variables & & & & & \\
W/PG or W/CG & 3.5 & 2.654 & & 3.5 & 4.860 \\
A/PG or A/CG & 5.5 & 4.752 & & 5.5 & 6.331 \\
Air 2 (kgmole/hr) & 50 & 33.25 & & 50 & 36.740 \\
Reformer's Parameters & & & & & \\
P (kpa) & 456 & 456 & & 456 & 456 \\
TR (oC) & 842.8 & 775.5 & & 729 & 765.8 \\
\hline
\end{tabular}

in accordance with the simulation results reported by Authayanun et al. [9]. The thermal efficiency calculated by Equation (24), was $79.51 \%$ for PG and $77.78 \%$ for CG. These values show that more than three-quarter of the energy supplied to the plant is obtained in the form of hydrogen (useful product) and that the remaining part of the energy gets lost to the environment. It can be noticed from this Table that a slight reduction of $1.73 \%$ in thermal efficiency was accomplished when CG was considered as feed. This might be attributed to increase in power consumption for feed pumping and air compression. This consequently led to 5.06 increments in specific energy consumption. It is worth noting that this analysis was based on the optimized simulation results shown in Table 3. It is observed that the thermal efficiency is very close to the values reported in the literature; glycerol: $83.6 \%$, [15] and gasoline: $82.84 \%$, [19].

\section{Exergy analysis}

The exergetic efficiencies of the system were computed to be 57.04 and $54.08 \%$ for PG and CG, respectively. The exergetic efficiency of $\mathrm{CG}$ is about $3 \%$ less than that of PG. This might probably due to internal exergy loss as result of numerous reactions taking place during reforming process. The exergetic efficiency of PG is approximately equal to the value obtained by Hajjaji et al. [16] (57\%). It is noticed that the exergetic efficiencies are less than thermal efficiencies. The inclusion of exergy destruction in the exergetic balance might responsible for the differences.

TABLE 4. Results obtained from simulation

\begin{tabular}{|c|c|c|}
\hline & PG & CG \\
\hline Hydrogen Productivity & 4.937 & 6.160 \\
\hline Energy Efficiency (\%) & 79.50 & 77.68 \\
\hline \multicolumn{3}{|l|}{ Power Consumption } \\
\hline Air Compression (kW) & 872.96 & 1148.58 \\
\hline Feed Pumping (kW) & 2.22 & 2.64 \\
\hline Total Power Consumed (kW) & 875.18 & 1151.22 \\
\hline $\begin{array}{l}\text { Specific Energy Consumption } \\
\text { (kWh/Nm³ hydrogen) }\end{array}$ & 0.079 & 0.083 \\
\hline
\end{tabular}

For the case of PG, an approximate value of $42.95 \%$ of the total exergy fed to the system is unused of which $74.51 \%$ of it disappears within the process plant as exergy destruction. With the CG as feed to the system, about $45.92 \%$ of the total exergy available for the process is not used. $77.79 \%$ of the exergy unused vanishes as internal exergy loss. It also indicated in Table 5 that $133.50 \mathrm{~kJ}$ of exergy is associated with production of 1 mole of $\mathrm{H}_{2}$ when PG is considered as feed. In the case of $\mathrm{CG}$, production of 1 mole of $\mathrm{H}_{2}$ caused $157.30 \mathrm{~kJ}$ of internal exergy loss. These could be ascribed to exergy loss caused by mixing of streams in the reactor, chemical reactions and heat transfer with wide temperature difference. These values are comparatively higher than the values reported in the literature for SMR, $100.60 \mathrm{~kJ} / \mathrm{mole}_{2}$ [20] and for ATR of glycerol, $98.82 \mathrm{~kJ} / \mathrm{mole}_{2}$ [16]. This higher value might be as a result of PSA included in this model.

TABLE 5. Summary of the results from the exergy analysis of the whole process plant

\begin{tabular}{lcc}
\hline Exergy exchanged & PG & CG \\
\hline Exergy in $\left(\mathrm{kJ} / \mathrm{moleH}_{2}\right)$ & 417.5 & 440.3 \\
Exergy out $\left(\mathrm{kJ} / \mathrm{moleH}_{2}\right)$ & 283.9 & 283.0 \\
Exergy destruction $\left(\mathrm{kJ} / \mathrm{moleH}_{2}\right)$ & 133.5 & 157.3 \\
Exergy unused $\left(\mathrm{kJ} / \mathrm{moleH}_{2}\right)$ & 179.3 & 202.2 \\
Exergy efficiency $(\%)$ & 57.04 & 54.08 \\
\hline
\end{tabular}

\section{CONCLUSION}

The simulation of ATR for hydrogen production was conducted using both PG and CG as feeds. The simulation model was optimized for maximum hydrogen production. The influence of other constituents apart from glycerol present in CG on hydrogen productivity, thermal efficiency and exergetic efficiency was investigated under thermoneutral condition. The optimized results indicated more generation of methane when CG was considered. It also shows that the presence of other constituents in $\mathrm{CG}$ contributed to increase in hydrogen productivity by increasing the energy demand of the plant but due to increase in both energy and exergy input, they decrease both the thermal and exergetic efficiencies.

\section{REFERENCE}

1. Kapdan, I.K. and Kargi, F., 2006. Bio-hydrogen production from waste materials. Enzyme and Microbial Technology, 38(5), pp.569-582.

2. Marchetti, J.M., Miguel, V.U. and Errazu, A.F., 2007. Possible methods for biodiesel production. Renewable and Sustainable Energy Reviews, 11(6), pp.1300-1311.

3. Hu, S., Luo, X., Wan, C. and Li, Y., 2012. Characterization of crude glycerol from biodiesel plants. Journal of Agricultural and Food Chemistry, 60(23), pp.5915-5921.

4. Zhang, B., Tang, X., Li, Y., Xu, Y. and Shen, W., 2007. Hydrogen production from steam reforming of ethanol and glycerol over ceriasupported metal catalysts. International Journal of Hydrogen Energy, 32(13), pp.2367-2373.

5. Iriondo, A., Barrio, V.L., Cambra, J.F., Arias, P.L., Guemez, M.B., Sanchez-Sanchez, M.C., Navarro, R.M. and Fierro, J.L.G., 2010 
Glycerol steam reforming over Ni catalysts supported on ceria and ceria-promoted alumina. International Journal of Hydrogen energy, 35(20), pp.11622-11633.

6. Wang, H., Wang, X., Li, M., Li, S., Wang, S. and Ma, X., 2009 Thermodynamic analysis of hydrogen production from glycerol autothermal reforming. International Journal of Hydrogen Energy, 34(14), pp.5683-5690.

7. Wang, W., 2010. Thermodynamic analysis of glycerol partial oxidation for hydrogen production. Fuel Processing Technology, 91(11), pp.1401-1408.

8. Kale, G.R. and Kulkarni, B.D., 2010. Thermodynamic analysis of dry autothermal reforming of glycerol. Fuel Processing Technology, 91(5), pp.520-530.

9. "Authayanun, S., Arpornwichanop, A., Paengjuntuek, W. and Assabumrungrat, S., 2010. Thermodynamic study of hydrogen production from crude glycerol autothermal reforming for fuel cell applications. International Journal of Hydrogen Energy, 35(13), pp.6617-6623.

10. Ortiz, F.G., Ollero, P. and Serrera, A., 2011. Thermodynamic analysis of the autothermal reforming of glycerol using supercritical water International Journal of Hydrogen Energy, 36(19), pp.12186-12199.

11. Abdulghani, A., 2014. Hydrogen Production by the Catalytic AutoThermal Reforming of Synthetic Crude Glycerol in a Packed Bed Tubular Reactor, Masters Thesis, University of Regina, Canada.

12. Swami, S.M. and Abraham, M.A., 2006. Integrated catalytic process for conversion of biomass to hydrogen. Energy \& Fuels, 20(6), pp.2616-2622.

13. Adhikari, S., Fernando, S., Gwaltney, S.R., To, S.F., Bricka, R.M.,
Steele, P.H. and Haryanto, A., 2007. A thermodynamic analysis of hydrogen production by steam reforming of glycerol. International Journal of Hydrogen Energy, 32(14), pp.2875-2880.

14. Jimmy, U., Mohamedali, M. and Ibrahim, H., 2017. Thermodynamic analysis of autothermal reforming of synthetic crude glycerol (SCG) for hydrogen production. ChemEngineering, 1(4), pp.1-12.

15. Da Silva, G.F., Mendes, J.S., Mota, F.A., Ferreira, A.L. and AN, F., 2010. Optimization of the Operating Conditions of Production Hydrogen from Glycerol Autothermal Reforming for fuel Cell. In $2^{\text {nd }}$ International Conference on Engineering Optimization, Portugal, pp.15.

16. Hajjaji, N., Baccar, I. and Pons, M.N., 2014. Energy and exergy analysis as tools for optimization of hydrogen production by glycerol autothermal reforming. Renewable Energy, 71, pp.368-380.

17. Lei, J., Yue, H., Tang, H. and Liang, B., 2015. Heat integration and optimization of hydrogen production for a $1 \mathrm{~kW}$ low-temperature proton exchange membrane fuel cell. Chemical Engineering Science, 123, pp.81-91.

18. 'Divins, N.J., López, E., Rodríguez, Á., Vega, D. and Llorca, J., 2013. Bio-ethanol steam reforming and autothermal reforming in $3-\mu \mathrm{m}$ channels coated with $\mathrm{RhPd} / \mathrm{CeO} 2$ for hydrogen generation. Chemical Engineering and Processing: Process Intensification, 64, pp.31-37.

19. Doss, E.D., Kumar, R., Ahluwalia, R.K. and Krumpelt, M., 2001. Fuel processors for automotive fuel cell systems: a parametric analysis. Journal of Power Sources, 102(1-2), pp.1-15.

20. Simpson, A.P. and Lutz, A.E., 2007. Exergy analysis of hydrogen production via steam methane reforming. International Journal of Hydrogen Energy, 32(18), pp.4811-4820.

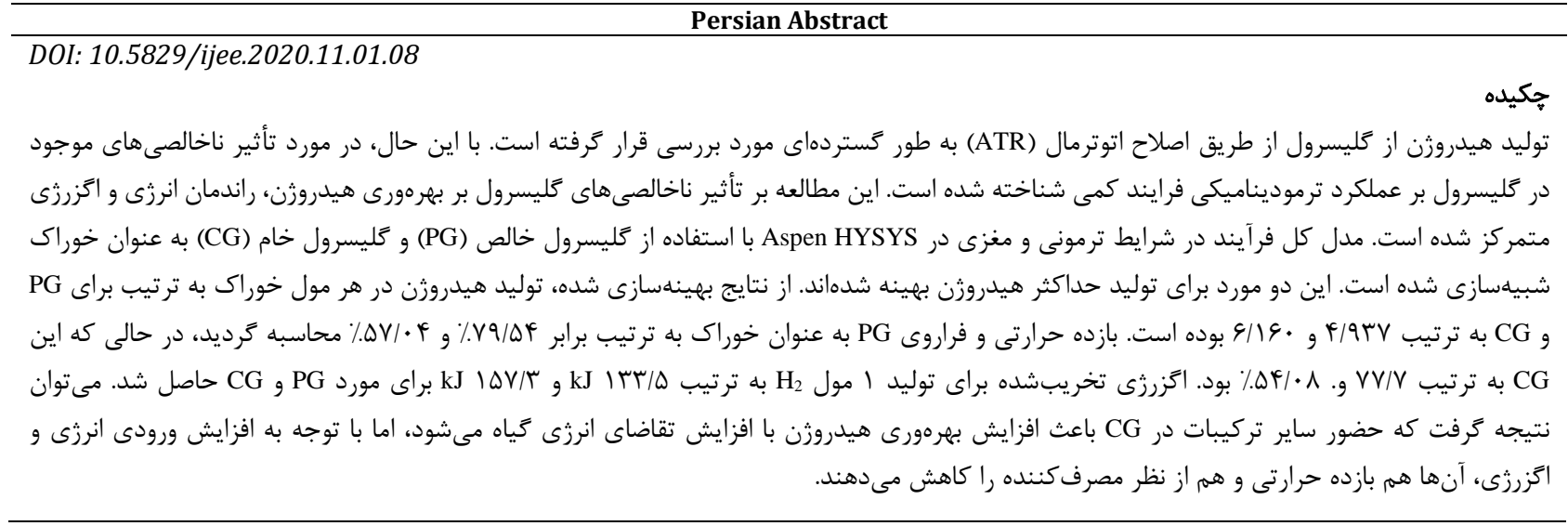

